\title{
Modal Sosial: Kekuatan dan Pertahanan di Bantaran Sungai
}

\author{
Social Capital: Strength and Defence in Riverbank
}

\author{
Sjarifah Salmah
}

Program Studi Kesehatan Masyarakat Fakultas Ilmu-ilmu Kesehatan Universitas Pembangunan Nasional Veteran Jakarta

\begin{abstract}
Abstrak
Di bantaran sungai Ciliwung terdapat permukiman penduduk seluas lebih dari 6 hektar yang berpotensi mengubah lahan menjadi kumuh, padat, dan tidak manusiawi yang berdampak pada kualitas lingkungan fisik dan nonfisik yang tidak sehat. Tujuan penelitian ini adalah untuk memperoleh gambaran karakter modal sosial yang dimiliki penduduk pemukim lama di bantaran sungai, menganalisis implikasi modal sosial terhadap kebijakan pemerintah, serta menyumbangkan model penerapan pemberdayaan modal sosial pada penataan bantaran sungai. Penelitian kualitatif yang dilengkapi data kuantitatif lapangan ini disebut kuasi kualitatif. Populasi penelitian ini adalah kualitas lingkungan fisik alami dan modal sosial komunitas yang bermukim sepanjang bantaran sungai Ciliwung. Sampel adalah kualitas fisik alami bantaran sungai dan modal sosial komunitas yang bermukim lama di bantaran sungai Ciliwung Manggarai. Lebih dari setengah karakter modal sosial milik komunitas bantaran sungai Ciliwung Manggarai dimanfaatkan untuk kegiatan sosial membantu sesama dalam kegiatan sosial, sisanya lumpuh oleh kondisi yang berkembang. Implikasi modal sosial akan bermanfaat apabila kekuatan modal sosial digerakkan dan diberdayakan optimal serta diarahkan untuk meningkatkan kualitas lingkungan hidup. Model pemberdayaan komunitas bantaran sungai Ciliwung Manggarai diskenariokan dengan menyandingkan kebijakan pemerintah pusat, daerah, dan kebijakan modal sosial yang dimanfaatkan untuk mengurangi kekumuhan permukiman di ibu kota dan meningkatkan kualitas lingkungan pada bantaran sungai Ciliwung Manggarai.
\end{abstract}

Kata kunci: Bantaran sungai, modal sosial, permukiman penduduk

\section{Abstract}

In the banks of Ciliwung river people live in more than 6 hectare areas that potentially turn into slum, full, and inhuman that affect on unhealthy physical and nonphysical quality. The purpose of this study is to obtain an overview of social capital character owned the old settlers along the river, analizing the implications of social capital towards government policies, and to donate empowerment model in the application of social capital in the arrangement of the riverbanks. Qualitative research incorporating quantitative data field is called quasi-qualitative. Population is the quality of the natural physical environment and social capital communities who live in Ciliwung riverbank. Samples are natural physical quality and the social capital of communities living in Ciliwung Manggarai riverbanks. More than half of the social capital there used for social activities such as helping others in social activities. The implications of social capital would be beneficial if its strength mobilized and empowered optimally and targetted to improve the quality of the environment. Community empowerment model in Ciliwung Manggarai riverbank is scripted by juxtaposing central government policy, regional policy, and social capital policy. It is used to reduce slum area and enhance environmental quality in Ciliwung Manggarai riverbanks.

Key words: Riverbanks, social capital, settlement area

\section{Pendahuluan}

Luas lahan bantaran sungai Ciliwung sejak dari hulu sampai hilir, mulai dari Pintu Air Manggarai sampai ke Ujung Jembatan Slamet Riyadi membentang lebih dari 6 hektar. ${ }^{1}$ Pertumbuhan penduduk yang terjadi secara alami dan migrasi berpotensi mengubah pola penggunaan lahan menjadi permukiman yang tidak sesuai dengan peruntukkan. Permukiman berubah menjadi kumuh, padat, dan tidak manusiawi dengan kualitas yang rendah dan tidak sehat. Pembangunan rumah tidak layak huni sepanjang bantaran sungai Ciliwung berdampak pada kualitas lingkungan fisik dan nonfisik yang tidak sehat. ${ }^{2}$

Kata modal sosial memberi makna dan nilai kekuat-

Alamat Korespondensi: Sjarifah Salmah, Prodi Kesmas Fakultas Ilmu-ilmu Kesehatan UPN Veteran Jakarta, Jl. RS Fatmawati Pondok Labu Jakarta Selatan 12450, Hp.0811165289, e-mail: syarifahsalmah@yahoo.com 
an yang perlu diperhatikan pada proses kehidupan komunitas di suatu lingkungan permukiman. Modal sosial pada dasarnya adalah nilai kepercayaan (mutual trust) antara penduduk dan masyarakat terhadap pimpinan. ${ }^{3}$ Kebijakan pemerintah daerah (pemda) menempatkan masyarakat sebagai pilar utama pemda secara ideal bertujuan untuk memberdayakan, menumbuhkan prakarsa dan kreativitas, dan meningkatkan peran serta masyarakat untuk meningkatkan kualitas hidup. ${ }^{4}$ Amanat Undang-Undang (UU) Nomor 32 Tahun 2004 dan transformasi cara pandang modal sosial merupakan perspektif kearifan lokal suatu wilayah yang bermanfaat untuk melestarikan lingkungan hidup. ${ }^{5}$ Biosfer yang maha kaya mengandung unsur tanah dan hara, air, dan udara diciptakan Tuhan untuk memenuhi kebutuhan proses kehidupan manusia, biota, dan mahkluk hidup yang lain. ${ }^{6}$ Semua makhluk berhak untuk hidup dan menempati lahan sesuai habitat, tetapi manusia dengan kelebihan akal dan pikiran secara moral dituntut menjadi makhluk sempurna yang peduli dan memelihara ekosistem kehidupan biota termasuk ekosistem sepanjang bantaran sungai. ${ }^{7}$ Modal sosial merupakan institusi sosial yang melibatkan jaringan, norma, dan kepercayaan, serta mendorong kolaborasi sosial berupa koordinasi dan kooperasi untuk kepentingan bersama. Modal sosial meliputi social bounding, social bridging, dan social linking. ${ }^{8}$

Social bounding berarti perekat sosial yang ada dan terpelihara di dalam suatu sistem kemasyarakatan. Sosial bounding mencakup nilai, kultur, persepsi, dan tradisi atau adat istiadat seperti sistem kekerabatan dengan nilai klen yang merupakan kelompok tradisional, unilateral, dan eksogam. Kelompok tradisional bermakna suatu hubungan warga atau kerabat yang tidak lagi dapat ditelusuri. Kelompok unilateral berarti hubungan garis keturunan dengan hanya memperhitungkan garis patrilineal atau matrilineal. Kelompok eksogam berupa hubungan karena perkawinan. Hubungan kekerabatan tersebut dapat membangun rasa empati kebersamaan dan simpati berkewajiban, percaya, resiprokal, serta pengakuan timbal balik nilai kebudayaan yang mereka percaya. Aturan main yang merupakan ketentuan atau kesepakatan bersama pada masyarakat dapat dalam bentuk formal dan informal. Bentuk formal berupa sanksi yang jelas seperti aturan undang-undang serta sanksi nonformal berupa pengucilan, rasa tidak hormat bahkan dianggap tidak ada dalam suatu lingkungan komunitas. Hal tersebut menimbulkan keseganan setiap anggota masyarakat untuk tidak ambil bagian dalam tanggung jawab dan mengakibatkan suasana keteraturan di dalam masyarakat (sosial order).

Social bridging atau jembatan sosial merupakan ikatan sosial yang timbul akibat reaksi terhadap berbagai macam karakteristik kelompok yang muncul akibat berbagai kelemahan sekitar dan keputusan membangun kekuatan dari kelemahan yang ada. Stephen Aldidgre, ${ }^{3}$ menggambarkan jembatan sosial sebagai "pelumas sosial" yang memperlancar roda-roda penghambat jalan modal sosial dalam suatu komunitas. Wilayah kerja jembatan sosial lebih luas dibandingkan social bounding dan dapat bekerja pada lintas kelompok etnis dan kepentingan. ${ }^{9}$

Social linking merupakan hubungan sosial yang dicirikan oleh hubungan pada berbagai level kekuatan sosial dalam masyarakat yang secara bersama berkepentingan mengadakan hubungan seperti hubungan antara elite politik dengan masyarakat umum. Elite politik dipandang khalayak sebagai public figure, tokoh yang mempunyai status sosial lebih baik dibandingkan masyarakat kebanyakan. Elite politik membutuhkan massa untuk mendapatkan suara pendukung, sementara masyarakat berusaha mendapatkan orang terpercaya untuk menjadikan penyalur aspirasi yang mereka percayai sebagai wakil.

Kebijakan pemerintah yang tertuang dalam UU Nomor 32 Tahun 2004 tentang Pemerintahan Daerah mengamanatkan 3 level kebijakan utama meliputi individu dan komunitas; kelurahan dan kecamatan; serta tingkat wilayah. ${ }^{10}$ Implikasi 13 karakter modal sosial terhadap kebijakan pemerintah perlu dipromosikan kepada masyarakat luas karena bermanfaat pada pemberdayaan dari masyarakat untuk masyarakat. Keterkaitan upaya mengurangi kekumuhan pemukiman dan meningkatkan kualitas lingkungan hidup di bantaran sungai. ${ }^{7}$ Kualitas komunitas di bantaran sungai Ciliwung Manggarai kurang sehat. Kualitas bantaran sungai juga tidak sesuai peruntukkan yang berfungsi alamiah sebagai lahan konservasi bervegetasi. Tujuan penelitian adalah untuk mendapatkan gambaran karakter modal sosial penduduk yang bermukim lama pada bantaran sungai, menganalisis implikasi modal sosial terhadap kebijakan pemerintah sebagai upaya pelestarian kualitas lingkungan bantaran sungai, serta menyumbangkan model penerapan pemberdayaan modal sosial pada penataan bantaran sungai.

\section{Metode}

Metode penelitian yang digunakan adalah pengamatan dan wawancara dengan pendekatan kuasi kualitatif. ${ }^{11}$ Daftar pertanyaan, sumber data, dan metode yang dimanfaatkan merujuk teori Woolcock dalam Prayitno (Tabel 1). ${ }^{3}$

Populasi adalah kualitas lingkungan fisik alami dan modal sosial komunitas yang bermukim sepanjang bantaran sungai Ciliwung mulai dari hulu di Kabupaten Bogor sampai hilir dan bermuara ke Teluk Jakarta. Sampel adalah kualitas fisik alami bantaran sungai dan modal sosial komunitas yang bermukim lama di bantaran sungai Ciliwung Manggarai. Lokasi bantaran sungai Ciliwung Manggarai dipilih karena pertimbangan ban- 
Tabel 1. Daftar Pertanyaan Penelitian, Sumber, dan Metode yang Dimanfaatkan

\begin{tabular}{|c|c|c|}
\hline Pertanyaan Penelitian & Sumber Data & Metode yang Dimanfaatkan \\
\hline $\begin{array}{l}\text { Bagaimana karakteristik modal sosial penduduk yang } \\
\text { lama bermukim di bantaran sungai Ciliwung Manggarai? }\end{array}$ & Primer dan sekunder & $\begin{array}{l}\text { Observasi (organisasi dan modal sosial), } \\
\text { wawancara, hasil penelitian terdahulu }\end{array}$ \\
\hline $\begin{array}{l}\text { Bagaimana implikasi modal sosial pada kebijakan } \\
\text { kualitas lingkungan di bantaran sungai Ciliwung Manggarai? }\end{array}$ & Primer dan sekunder & $\begin{array}{l}\text { Observasi, membandingkan penelitian terdahulu, kebijakan } \\
\text { kelembagaan, kepustakaan (laporan, buku) }\end{array}$ \\
\hline $\begin{array}{l}\text { Bagaimana model pemberdayaan modal sosial } \\
\text { di komunitas bantaran sungai Ciliwung Manggarai? }\end{array}$ & Skenario & $\begin{array}{l}\text { Menyandingkan kebijakan pemerintah pusat, daerah, dan } \\
\text { modal sosial komunitas bantaran sungai Ciliwung Manggarai }\end{array}$ \\
\hline
\end{tabular}

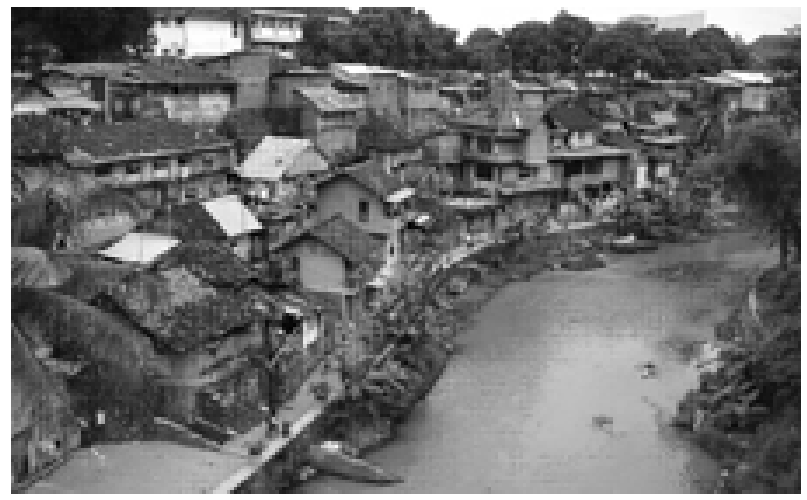

Gambar 1. Kondisi Lingkungan Fisik Bantaran Sungai Cho-de Yogyakarta

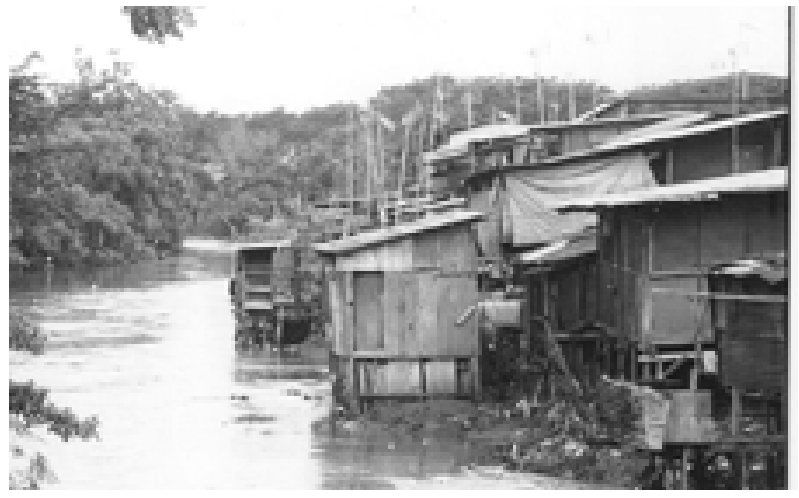

Gambar 2. Kondisi Lingkungan Fisik Bantaran Sungai Ciliwung Jakarta taran sungai Ciliwung melintasi Kabupeten Bogor Provinsi Jawa Barat di bagian hulu dan Provinsi Daerah Khusus Ibu Kota (DKI) Jakarta di bagian hilir sekitar 76 km. ${ }^{12}$ Pemukiman pada bantaran sungai Ciliwung Manggarai merupakan salah satu lokasi yang berdampak pada penyempitan badan sungai. ${ }^{7}$ Kebijakan pemerintah DKI Jakarta yang menyatu dengan konsep pengelolaan lingkungan sungai lebih terarah pada aspek fisik kualitas air sungai yang melampaui baku mutu air minum akibat pencemaran seperti program kali bersih serta pengerukan sedimentasi sungai dan ruang terbuka hijau. Penanganan banjir rutin lebih bersifat kebijakan sesaat untuk mengevakuasi penduduk serta memberikan makanan dan kebutuhan lain. Setelah banjir, warga kembali ke pemukiman tanpa perubahan yang mampu memperbaiki kualitas hidup menjadi lebih sehat dan manusiawi. ${ }^{7}$ Komunitas pemukim bantaran sungai Ciliwung Manggarai mempunyai modal sosial yang belum tersentuh untuk diberdayakan.

\section{Hasil}

Gambaran karakter modal sosial dan wujud penerapannya pada komunitas bantaran sungai Ciliwung Manggarai dapat dilihat pada Tabel 2. Dari 13 karakter modal sosial yang diobservasi, 8 karakter $(61,5 \%)$ diterapkan dalam kegiatan sehari-hari pada komunitas sebatas kegiatan sosial, namun tidak terarah pada pengurangan kekumuhan pemukiman dan konservasi lahan banta- ran sungai. Sekitar 5 karakter (38,5\%) yang terdiri dari karakter pelestarian lingkungan, adat dan nilai budaya lokal, kearifan lokal dan pengetahuan lokal, kesediaan mendengar, serta kemandirian, tidak ada penerapan dalam keberlanjutan lingkungan hidup di bantaran sungai bahkan terkesan dilumpuhkan oleh kondisi yang berkembang. Penguasa wilayah tidak mempunyai cara pandang terpadu terhadap pelestarian bantaran sungai. Sebagai pembanding terjadi perbedaan hasil penerapan modal sosial di 2 lokasi yaitu perbedaan kondisi lingkungan fisik bantaran sungai Cho-de, ${ }^{13}$ dan bantaran sungai Ciliwung Manggarai (Gambar 1 dan Gambar 2).

Bantaran sungai Ciliwung Manggarai dimanfaatkan penduduk sejak tahun 1953 dan sampai kini pemukiman meluas ke badan sungai dengan kualitas lingkungan yang tidak sehat. Modal sosial milik komunitas belum pernah diberdayakan dari mereka untuk mereka. Belum ada peran aktif dari pemangku wilayah. Sebaliknya, modal sosial komunitas bantaran sungai Cho-de telah diberdayakan sejak tahun 1970 dengan peran aktif tokoh masyarakat dan didukung kelembagaan wilayah sehingga kualitas lingkungan lebih baik. Berdasarkan fakta, penguasa wilayah DKI Jakarta kurang mempermasalahkan fungsi alami bantaran sungai sebagai lahan konservasi bervegetasi, yang ada justru tolak-menolak kepentingan. Dinas Pekerjaan Umum DKI Jakarta menginformasikan pengelolaan sungai Ciliwung menjadi wewenang Kementerian Pekerjaan Umum pemerintah 
Tabel 2. Karakter dan Penerapan Modal Sosial di Komunitas Bantaran Sungai Ciliwung Manggarai

\begin{tabular}{|c|c|c|c|c|}
\hline \multicolumn{2}{|c|}{ Kriteria Modal Sosial } & \multirow{2}{*}{ Wujud Nyata Modal Sosial } & \multicolumn{2}{|c|}{ Penerapan } \\
\hline Tipe & Karakter & & Ada & Tidak Ada \\
\hline \multirow[t]{5}{*}{ Social bounding } & Pelestarian lingkungan & $\begin{array}{l}\text { Komunitas bantaran sungai Ciliwung Manggarai tidak mengenal } \\
\text { pelestarian lingkungan dalam arti konservasi lahan bantaran sungai } \\
\text { dan tidak pernah mendapat penyuluhan tentang fungsi alamiah } \\
\text { bantaran sungai }\end{array}$ & - & $\mathrm{v}$ \\
\hline & Adat dan nilai budaya lokal & $\begin{array}{l}\text { Tidak berdampak konservasi dan pelestarian lingkungan } \\
\text { bantaran sungai Ciliwung Manggarai }\end{array}$ & - & $\mathrm{v}$ \\
\hline & Kearifan dan pengetahuan lokal & $\begin{array}{l}\text { Harus siap mengantisipasi banjir karena terbiasa dan rutin, } \\
\text { masyarakat tidak mengetahui fungsi alamiah bantaran sungai } \\
\text { dan manfaat bagi kehidupan, TV hanya dipakai nonton sinetron }\end{array}$ & $\mathrm{v}$ & $\mathrm{v}$ \\
\hline & Tanggung jawab sosial & $\begin{array}{l}\text { Ada, terutama menghadapi masalah sosial seperti menjenguk } \\
\text { warga sakit, gotong royong membantu karena punya dana sosial } \\
\text { dari iuran warga }\end{array}$ & $\mathrm{v}$ & - \\
\hline & Toleransi & $\begin{array}{l}\text { Toleransi spontan dan saling menghargai pendapat, } \\
\text { terutama sesama anggota jika ada rumor penggusuran }\end{array}$ & $\mathrm{v}$ & - \\
\hline \multirow[t]{2}{*}{ Social bridging } & Kesediaan mendengar & $\begin{array}{l}\text { Mau mendengar informasi dari warga atau televisi, } \\
\text { alergi dengan pendatang baru mengatasnamakan LSM atau } \\
\text { NGO's dan janji pemerintah tidak pernah datang }\end{array}$ & $\mathrm{v}$ & $\mathrm{v}$ \\
\hline & Partisipasi masyarakat & $\begin{array}{l}\text { Ada, terutama menghadapi kebutuhan sosial, hajatan, } \\
\text { pernikahan, dan memelihara MCK }\end{array}$ & $\mathrm{v}$ & - \\
\hline \multirow[t]{6}{*}{ Social linking } & Hubungan sosial & $\begin{array}{l}\text { Ada interaksi antarindividu dan kepedulian membantu sesama } \\
\text { seperti kerja di bengkel motor dan lapas barang bekas }\end{array}$ & $\mathrm{v}$ & - \\
\hline & Jaringan dan kepemimpinan sosial & $\begin{array}{l}\text { Ada, ketua RW } 04 \text { yang dianggap mampu mengayomi dan } \\
\text { melindungi warga sehingga warga bertahan di bantaran sungai } \\
\text { meskipun terancam banjir }\end{array}$ & $\mathrm{v}$ & - \\
\hline & Kepercayaan & $\begin{array}{l}\text { Ada kepercayaan pada pengurus RT dan PKK yang aktif } \\
\text { membantu kegiatan pelayanan kesehatan seperti PIN }\end{array}$ & $\mathrm{v}$ & - \\
\hline & Kebersamaan dan kesetiaan & $\begin{array}{l}\text { Ada, saat musibah, merasa senasip, dan membantu sesama } \\
\text { seperti mengurus jenazah sampai ke liang lahat yang mahal }\end{array}$ & $\mathrm{v}$ & - \\
\hline & Kemandirian & $\begin{array}{l}\text { Kekuatan sosial di komunitas tidak diberdayakan, } \\
\text { meningkatkan kualitas hidup warga, terkesan membuat } \\
\text { warga lumpuh, tidak kreatif, dan tidak berpikir }\end{array}$ & - & $\mathbf{v}$ \\
\hline & Kejujuran & $\begin{array}{l}\text { Ada, menyampaikan informasi yang mengancam } \\
\text { seperti banjir atau penggusuran. Namun, mereka belum pernah } \\
\text { mendengar penggusuran di wilayah mereka }\end{array}$ & $\mathrm{v}$ & - \\
\hline
\end{tabular}

pusat karena melibatkan 2 provinsi. Pihak pemerintah pusat (Balai Besar Proyek Pengelolaan Sungai CisadaneCiliwung) menyatakan bahwa pemukim bantaran sungai adalah warga DKI Jakarta, jadi pemerintah DKI yang bertanggung jawab untuk memindahkan warganya. Urusan aliran sungai meliputi pengerukan sedimentasi dan penghijauan menjadi urusan Balai Besar Proyek Pengelolaan Sungai Cisadane-Ciliwung.

Untuk mengurangi kekumuhan pemukiman dan meningkatkan kualitas lingkungan pada bantaran sungai Ciliwung Manggarai, model pemberdayaan kebijakan penataan bantaran sungai Ciliwung Manggarai yang diskenariokan adalah mencari keseimbangan kebijakan. Tidak terlihat satu pasal pun dari kebijakan pemerintah pusat dan daerah yang memuat ketentuan penataan bantaran sungai sebagai lahan konservasi (Tabel 3).

\section{Pembahasan}

Berdasarkan hasil penerapan 13 karakter modal sosial tersebut, lama tinggal komunitas lebih dari setengah abad yang bermukim di bantaran sungai Ciliwung
Manggarai tidak memberikan hasil yang mampu meningkatkan kualitas lingkungan hidup. Yang terjadi adalah kerusakan fungsi alami bantaran sungai bertambah melebar sampai ke badan air. Dari 13 karakter modal sosial yang diobservasi, lebih dari setengah jumlah karakter terarah hanya sebatas kegiatan sosial. Kurang dari separuh karakter tidak terarah untuk mengurangi kekumuhan pemukiman dan konservasi lahan bantaran sungai bahkan terkesan dilumpuhkan oleh kondisi yang berkembang. Dikaitkan dengan kebijakan pemerintah yang mengamanatkan pengaktifan peran serta masyarakat mulai dari level bawah, penguasa wilayah belum mempunyai cara pandang yang sama dan terpadu terhadap pelestarian bantaran sungai. Kondisi ini tidak berjalan karena cara pandang terhadap fungsi alami bantaran sungai dan komunitas bermukim yang salah. ${ }^{7}$ Pandangan salah terhadap fungsi alamiah bantaran sungai karena penduduk tidak menyadari manfaat ekosistem bantaran sungai bagi kehidupan makhluk lain, penduduk bermukim di bantaran sungai dipandang ilegal karena bukan penduduk Jakarta. Hal ini bertentangan dengan amanat Undang- 
Tabel 3. Model Pemberdayaan Kebijakan Penataan Bantaran Sungai Ciliwung Manggarai

\begin{tabular}{|c|c|c|}
\hline \multicolumn{2}{|c|}{ Kriteria Kebijakan } & \multirow{2}{*}{ Penerapan Kebijakan Penataan Bantaran Sungai Ciliwung Manggarai } \\
\hline Tertulis & Tidak Tertulis & \\
\hline $\begin{array}{l}\text { UU no. } 7 \text { tahun } 2004 \\
\text { tentang sumber daya air }\end{array}$ & - & $\begin{array}{l}\text { Tidak ada pasal memuat kebijakan penataan bantaran sungai, tidak menjelaskan } \\
\text { lebar bantaran atau garis sempadan sungai }\end{array}$ \\
\hline $\begin{array}{l}\text { UU no. } 32 \text { tahun } 2004 \\
\text { tentang pemerintah daerah }\end{array}$ & - & $\begin{array}{l}\text { Penjelasan umum menempatkan masyarakat pilar utama pemerintah daerah. } \\
\text { Tujuan ideal yaitu memberdayakan, menumbuhkan prakarsa dan kreativitas, } \\
\text { meningkatkan peran serta agar terjadi perubahan ke arah yang lebih baik } \\
\text { termasuk penataan ruang bantaran sungai dengan memanfaatkan modal sosial }\end{array}$ \\
\hline $\begin{array}{l}\text { Keppres no. } 32 \text { tahun } 1990 \\
\text { rencana tata ruang } \\
\text { wilayah nasional }\end{array}$ & - & $\begin{array}{l}\text { Hanya menginformasikan lebar sempadan sungai pada sungai besar di luar tentang } \\
\text { pemukiman (minimal } 100 \mathrm{~m} \text { ) dan pada anak sungai besar (minimal } 50 \mathrm{~m} \\
\text { di kedua sisi). Di daerah pemukiman, lebar bantaran cukup membangun jalan } \\
\text { inspeksi }(10-15 \text { meter) }\end{array}$ \\
\hline $\begin{array}{l}\text { Kebijakan BB pengelolaan } \\
\text { Sungai Ciliwung Cisadane } \\
\text { Kementerian PU }\end{array}$ & & $\begin{array}{l}\text { Pengelolaan Sungai Ciliwung diarahkan pada pengerukan sedimentasi badan sungai } \\
\text { dan ruang terbuka hijau (Bagian Perencanaan BBPSCC, 2007: hasil wawancara) }\end{array}$ \\
\hline $\begin{array}{l}\text { Kebijakan Perda no. } 6 \\
\text { tahun } 1999 \text { tentang RT RW } \\
\text { DKI Jakarta } 2010\end{array}$ & & $\begin{array}{l}\text { Tidak satu pasal pun terarah pada penataan bantaran sungai terpadu antara } \\
\text { konservasi bantaran dan pemukiman penduduk di bantaran, pengembangan lebih } \\
\text { diarahkan pada pengelolaan koridor sungai }\end{array}$ \\
\hline- & Modal sosial milik komunitas & $\begin{array}{l}\text { Memuat } 13 \text { unsur modal sosial yang belum optimal dimanfaatkan dan diberdayakan } \\
\text { untuk meningkatkan kualitas lingkungan komunitas secara terpadu dan bertahap, } \\
\text { mulai penataan pemukiman sampai penataan konservasi lahan bantaran } \\
\text { sungai Ciliwung Manggarai }\end{array}$ \\
\hline
\end{tabular}

\section{Undang Dasar 1945. ${ }^{14}$}

Hasil penelitian yang menginformasikan penduduk telah bermukim di bantaran sungai Ciliwung Manggarai lebih setengah abad tepatnya sejak tahun 1953 dengan 6 kepala keluarga sebagai penghuni perdana dan sampai saat ini tidak satu pun kebijakan pemerintah yang memperhatikan peruntukan bantaran sungai dan kondisi penduduk yang tidak manusiawi. Hal tersebut memperlihatkan kelemahan pemerintah, yaitu Kementerian Pekerjaan Umum berjalan sendiri yang terlihat pada kegiatan pengerukan sedimentasi yang diserahkan pada Balai Besar Proyek Pengelolaan Sungai CiliwungCisadane, termasuk membangun ruang terbuka hijau. Pemerintah DKI Jakarta juga berjalan sendiri terlihat pada operasional kebijakan membuat koridor sungai. Kegiatan yang dilaksanakan kedua pihak tersebut tidak terkoordinasi dan terpadu. Hal ini bertentangan dengan amanat kebijakan lingkungan hidup sehingga tidak menjawab kebutuhan mengurangi kekumuhan permukiman dan meningkatkan kualitas lingkungan secara fisik, sosial, dan ekonomi. Dalam kondisi tolak-menolak kepentingan pengelolaam bantaran sungai, implikasi pemanfaatan modal sosial yang dimiliki individu dan komunitas terhadap kebijakan pemerintah menjadi penting dan secara langsung maupun tidak langsung berkontribusi besar dalam mendukung pelestarian fungsi lingkungan hidup.

Ada 3 level kebijakan utama yang penting di tingkat individu dan komunitas. Pada level ini, modal sosial milik individu dan komunitas memberikan dukungan sebagai ujung tombak modal sosial. Hal ini diharapkan dapar mewujudkan efisiensi dan efektivitas pencapaian tujuan bersama lingkungan hidup sehat untuk menciptakan konservasi bantaran sungai dan membangun pemukiman yang aman dan bebas banjir. Aspirasi masyarakat level bawah sebagai karakter modal sosial wajib didengar karena masyarakat bawah mengetahui permasalahan. Oleh karena itu, masukan yang diberikan merupakan akar permasalahan yang perlu dipelajari, disimak, dan disikapi untuk mendapatkan solusi yang tepat dan terarah untuk mencapai tujuan bersama. Modal sosial milik komunitas merupakan pendukung yang membutuhkan pendampingan biaya operasional dari sponsor sosial. Dana menjadi kebutuhan dasar untuk menciptakan "jalan mulus" menuju sukses.

Di setiap level kelurahan dan kecamatan, modal sosial bermanfaat sebagai ajang promosi pengembangan kekuatan modal sosial komunitas bantaran sungai di Kelurahan Manggarai dan Kecamatan Tebet yang merupakan jaringan kerja sama antarkomunitas di lokasi lahan bantaran sungai Ciliwung Manggarai dan lokasi lain dengan masalah dan kondisi yang sejenis serta pengembangan informasi bersama komunitas lain dengan lokasi dan bentangan alam yang sama dengan bantaran sungai Ciliwung Manggarai.

Di level wilayah (Kotamadya Jakarta Selatan) dan DKI Jakarta, modal sosial berkontribusi kuat menemukan akar permasalahan komunitas. Modal sosial tampil sebagai wujud pengembangan kebijakan yang partisipatif antara warga masyarakat di bantaran sungai Ciliwung Manggarai dan tingkat wilayah Jakarta Selatan. Pengembangan jaringan pemberdayaan kekuatan modal 
sosial pada berbagai bantaran sungai di wilayah DKI Jakarta dengan kondisi yang sama atau hampir sama.

Implikasi modal sosial terhadap kebijakan pemerintah penting dipromosikan kepada masyarakat luas karena penurunan kualitas lingkungan hidup yang serupa banyak terjadi di berbagai bantaran sungai lain. ${ }^{15}$ Bantaran sungai Ciliwung Manggarai hanya salah satu dari ratusan bantaran sungai yang dipadati pemukiman penduduk yang hampir sama atau bahkan lebih buruk. Pemerintah tidak akan pernah mengalokasikan dana untuk meningkatan kualitas warga di bantaran sungai karena dana yang terbatas dan cara pandang yang salah terhadap pengelolaan bantaran sungai. Warga komunitas bantaran sungai Ciliwung Manggarai harus mulai menanamkan rasa untuk mau memperbaiki kualitas lingkungan hidup dengan kekuatan komunitas. ${ }^{16}$

\section{Kesimpulan}

Lebih dari setengah karakter modal sosial yang dimiliki komunitas bantaran sungai Ciliwung Manggarai dimanfaatkan untuk kegiatan sosial membantu sesama, sisanya tidak dimanfaatkan karena terkesan dilumpuhkan oleh kondisi yang berkembang pada bantaran sungai. Implikasi modal sosial terhadap kebijakan pengelolaan bantaran sungai akan bermanfaat apabila kekuatan modal sosial yang dimiliki komunitas bantaran sungai Ciliwung Manggarai digerakkan dan diberdayakan secara optimal dan terarah untuk meningkatkan kualitas lingkungan hidup bantaran sungai Ciliwung Manggarai. Model pemberdayaan komunitas bantaran sungai Ciliwung Manggarai diskenariokan dengan menyandingkan 3 kebijakan yaitu kebijakan pemerintah pusat, pemda, dan kebijakan modal sosial yang dimanfaatkan untuk mengurangi kekumuhan pemukiman di ibu kota dan meningkatkan kualitas lingkungan pada bantaran sungai Ciliwung Manggarai.

\section{Saran}

Sebagai solusi, model yang disarankan adalah permasalahan lingkungan bantaran sungai Ciliwung Manggarai tidak dilihat hanya dari satu sisi atau secara parsial, tetapi harus dilihat secara multidisplin ilmu dan multisektor terkait. Pengelolaan wajib dipadukan dan dikoordinasikan dengan selalu mempertimbangkan ketiga komponen lingkungan hidup fisik, sosial ekonomi, dan binaan yang saling terkait, berhubungan secara timbal balik dan terintegrasi, harmonis, serta terversifikasi. Sebagai penguasa wilayah, pemerintah wajib menggerakkan dan memberdayakan kekuatan modal sosial yang dimiliki warga di setiap level, mulai dari individu, komunitas, dan wilayah secara berdaya dan berhasil guna. Pemerintah sebagai fasilitator tidak dapat menghentikan kegiatan pemberdayaan komunitas sebelum diperoleh hasil yang optimal. Dibutuhkan perangkat hukum untuk mendisplinkan setiap aparatur pemerintah dalam menjalankan pengabdian sebagai abdi masyarakat dan negara. Sebagai fasilitator, pemerintah wajib memfasilitasi kebutuhan pendukung, berkoordinasi dengan instansi dan institusi terkait serta para ahli sesuai bidangnya. Selain itu, perlu melakukan pemantauan dan evaluasi kegiatan yang dilakukan sampai hasil akhir dicapai. Sebagai ukurannya, komunitas dapat menikmati hasil jerih payah yang telah dimanfaatkan untuk meningkatkan kualitas hidup mereka, dari mereka dan untuk mereka.

\section{Daftar Pustaka}

1. Pemerintah Daerah Khusus Ibu Kota Jakarta. Data penduduk sepanjang bantaran Kali Ciliwung Kelurahan Manggarai. Jakarta: Pemerintah Daerah Khusus Ibu Kota Jakarta; 2002.

2. Irianto G. Alih fungsi lahan bantaran sungai dan dampaknya terhadap produksi air DAS dan banjir. Jurnal Sinar Tani. 2004.

3. Singgih PU. Modal sosial dan ketahanan ekonomi keluarga miskin (studi sosiologi pada komunitas bantaran sungai Ciliwung) [disertasi]. Depok: Program Studi Ilmu Sosial Universitas Indonesia; 2004.

4. Sekretaris Negara. Undang-Undang nomor 32 tahun 2004 tentang pemerintahan daerah. Jakarta: Sekretaris Negara Republik Indonesia; 2004

5. Soetaryono R. Manusia, sumber daya alam, wilayah, dan tanggung jawab negara dalam undang-undang pengelolaan lingkungan hidup. Jurnal Lingkungan Hidup. 2006.

6. Soerjani M. Ekologi manusia. Edisi kedua. Pusat Penerbitan Universitas terbuka; 2002.

7. Salmah. Penataan bantaran sungai ditinjau dari aspek lingkungan, kajian pada bantaran sungai Ciliwung Manggarai [disertasi]. Jakarta: Program Studi Ilmu Lingkungan Universitas Indonesia Program Pascasarjana Universitas Indonesia; 2008.

8. Ancok D. Modal sosial dan kualitas masyarakat. Pidato pengukuhan jabatan guru besar Universitas Gadjah Mada, Yogyakarta, 3 Mei 2003.

9. Darundono. Peran modal sosial dalam proyek pembangunan kampung. Jurnal Ilmu Lingkungan Hidup. 2006.

10. Suganda E. Penataan ruang kawasan perkotaan pantai dalam pembangunan berkelanjutan [disertasi]. Jakarta: Program Studi Kajian Ilmu Lingkungan Program Pascasarjana Universitas Indonesia; 2007.

11. Moleong LJ. Metodologi penelitian kualitatif. Bandung: PT Remaja Rosdakarya; 2000.

12. Pemerintah Daerah Khusus Ibu Kota Jakarta. Hasil pendataan bangunan pinggiran Kali Ciliwung. Jakarta: Pemerintah Daerah Khusus Ibu Kota Jakarta; 2002.

13. Lindfield M. Indonesia housing finance for the poor, institute for housing, and urban development studies. 2000.

14. Undang-Undang Dasar Tahun 1945 Pasal 28 A, 28 C ayat (1) dan (2).

15. Masnellyarti H. Peningkatan konservasi sumber daya alam dan pengendalian kerusakan lingkungan. Laporan hasil penelitian Deputi Menteri Negara Lingkungan Hidup. Jakarta; Kementerian Lingkungan Hidup; 2004.

16. Atmanto D. Pendekatan sosiohidraulik dalam pengelolaan kualitas air sungai (studi kasus pengelolaan Sungai Ciliwung DKI Jakarta dan Sungai Citarum Kabupaten Bandung Jawa Barat) [disertasi]. Jakarta: Program Studi Ilmu Lingkungan Universitas Indonesia; 2007. 